
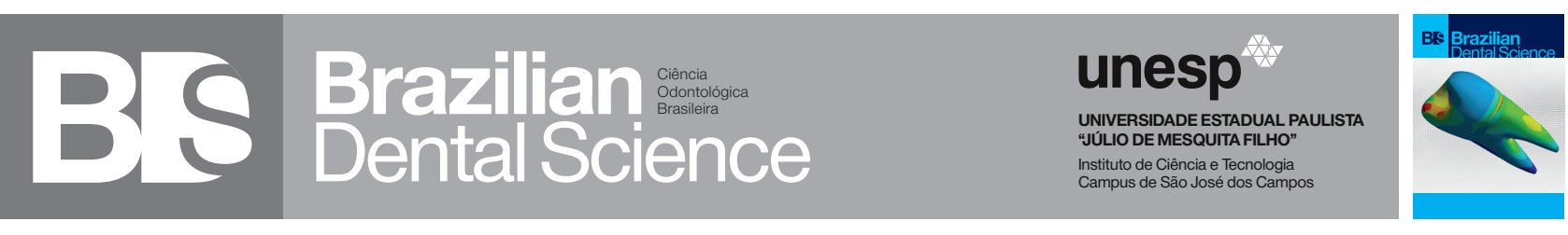

\title{
Knowledge and attitudes of students and dentists about the use and cementation of intra-radicular posts
}

\author{
Conhecimentos e atitudes de estudantes e dentistas sobre o uso e cimentação de pinos intrarradiculares
}

José Augusto SEDREZ-PORTO ${ }^{1}$, Rafael SARKIS-ONOFRE ${ }^{2}$, Aline Pinheiro de MORAES ${ }^{1}$, Marcos Britto CORREA ${ }^{1}$, Maximiliano Sérgio CENCI $^{1}$, Tatiana PEREIRA-CENCI ${ }^{1}$

1 - Graduate Program in Dentistry - Federal University of Pelotas - Pelotas - RS - Brazil.

2 - Graduate Program in Dentistry - IMED - Passo Fundo - RS - Brazil.

\begin{abstract}
Objectives: The aim of the study was assess the knowledge and attitudes of students and dentists about the use and cementation of intra-radicular posts. Material and Methods: This cross-sectional study interviewed 150 students and 150 dentists in the city of Pelotas (Brazil). A questionnaire containing questions regarding restorative choice in teeth with large coronal destruction, level of confidence for the use of post and resin cement, function of intra-radicular posts and social-demographic characteristics was applied. Data were analysed using descriptive analysis and associations were tested through logistic regression using 95\% confidence intervals. Results: The analysis showed that students presented an odd to choose prefabricated posts $127 \%$ greater than the dentists for anterior teeth, $105 \%$ greater to choose self-adhesive resin cement and $46 \%$ greater to choose conventional resin cement. Considering posterior teeth, students presented an odd to choose prefabricated posts $40 \%$ smaller than the dentists and an odd $51 \%$ greater to choose conventional resin cement. Conclusion: The formation level (students or dentists) was directly related to clinical choices of the interviewed. The use of prefabricated posts seems to be related to the location of the tooth in the arch, with pre-fabricated posts being more indicated for anterior teeth. Use of pre-fabricated posts in teeth with large coronal destruction is accepted in the literature. However, dentists are still not confident to use of pre-fabricated fiber posts especially in posterior teeth with large coronal destruction.
\end{abstract}

\section{KEYWORDS}

Resin cements; Post and core technique; Health knowledge, attitudes, practice.

\section{RESUMO}

Objetivo: o objetivo do estudo foi avaliar o conhecimento e as atitudes dos alunos e dentistas sobre o uso e cimentação de pinos intra-radiculares. Material e Métodos: este estudo transversal entrevistou 150 estudantes e 150 dentistas na cidade de Pelotas (Brasil). Foi aplicado um questionário contendo perguntas sobre a escolha restauração em dentes com grande destruição coronária, nível de confiança para o uso de pinos e cimento resinoso, função dos pinos intra-radiculares e características sociodemográficas. Os dados foram analisados utilizando análise descritiva e as associações foram testadas através de regressão logística usando intervalos de confiança de 95\%. Resultados: A análise mostrou que os alunos apresentaram uma chance para escolher pinos pré-fabricados $127 \%$ maior que os dentistas para dentes anteriores, 105\% maior para escolher cimento resinoso autoadesivo e $46 \%$ maior para escolher o cimento resinoso convencional. Considerando os dentes posteriores, os estudantes apresentaram uma chance para escolher os pinos pré-fabricados $40 \%$ menor do que os dentistas e uma chance $51 \%$ maior para escolher o cimento resinoso convencional. Conclusão: O nível de formação (estudantes ou dentistas) está diretamente relacionado às escolhas clínicas dos entrevistados. O uso de pinos préfabricados parece estar relacionado à localização do dente no arco, com pinos pré-fabricados sendo mais indicados para os dentes anteriores. O uso de pinos pré-fabricados em dentes com grande destruição coronária é aceito na literatura. No entanto, os dentistas ainda não estão confiantes para o uso de pinos pré-fabricados de fibra, especialmente em dentes posteriores com grande destruição coronária.

\section{PALAVRAS-CHAVE}

Cimentos de resina; Técnica pino e núcleo; Conhecimentos, atitudes, práticas de saúde. 


\section{INTRODUCTION}

$\mathrm{R}$ estoration of endodontically treated teeth (ETT) is still a challenge in clinical practice because there are many possible uses of materials and techniques. One of the worst-case scenarios for restoration of ETT is the absence of coronal walls with need of use of an intra-radicular post to provide a better retention for restorative material [13]. Several types of intra-radicular posts are available including cast metal posts and prefabricated posts [4-6]. Moreover, various luting agents as zinc phosphate and self-adhesive/ conventional resin cements may be used to lute these posts $[7,8]$. Taking this variety of materials into consideration, it is essential that dental students as well as dentists have sufficient knowledge about available materials and techniques to reach a better performance of restorations and consequently, longevity of restorative treatment.

Although dentists are expected to present better technical skills compared to students, some factors could influence the choices and longevity of materials/techniques such as workplace, time since graduation, post graduate training and capability to keep updated [9-11]. Nevertheless, and from the best of our knowledge, there is no report in the literature about the association between the knowledge about the use of intraradicular posts and cementation techniques of dental students and dentists. Also, there is no report evaluating whether students learning are according to the literature and whether students and dentists follow the literature recommendations.

Thus, the aim of the present study was to evaluate the knowledge and attitudes of dental students and dentists about the use and cementation of intra-radicular posts.

\section{MATERIAL AND METHODS}

This cross-sectional study was approved by the Local Ethics Committee (222/2011) and performed between August 2013 and December 2014, in Pelotas, in the southern region of Brazil. The research was conducted with dental students of the School of Dentistry of the Federal University of Pelotas $(\mathrm{N}=150)$, as well as with dentists of the same city $(\mathrm{N}=150)$, through a face-to-face interview (Total $\mathrm{N}=300$ ).

The following information was gathered by questionnaire application: social demographic characteristics (age and gender), clinical experience of dentists (time since graduation in years), post graduate training (specialist or not), workplace (public/private or both practice). Figure 1 shows clinical cases with large coronal destruction of anterior and posterior teeth used in the questionnaire to simulate a real experience that could occur on a day-day clinical professional. Information on the use of posts to restore ETT was collected as follow: choice of post (cast metal or pre-fabricated) and cement (zinc phosphate, glass ionomer, self-adhesive or conventional resin cement) for each clinical case of Figure 1, function of the intra-radicular posts (retention of restorative material and/or reinforcement of dental structure), type of coronal restoration (crown or composite resin) used in teeth with large coronal destruction, level of confidence for the use of glass fiber post and resin cement in teeth with large coronal destruction using a visual analogy scale (VAS $-0=$ no confidence and $10=$ totally confidence).

Initially, a pre-piloted questionnaire was applied with dentists from another city. In the first stage of research, students who had already learned about the topic $(n=150)$ were separated in small groups and received an explanation about the questionnaire prior to receive it to respond individually. Next, 150 dentists were randomly 


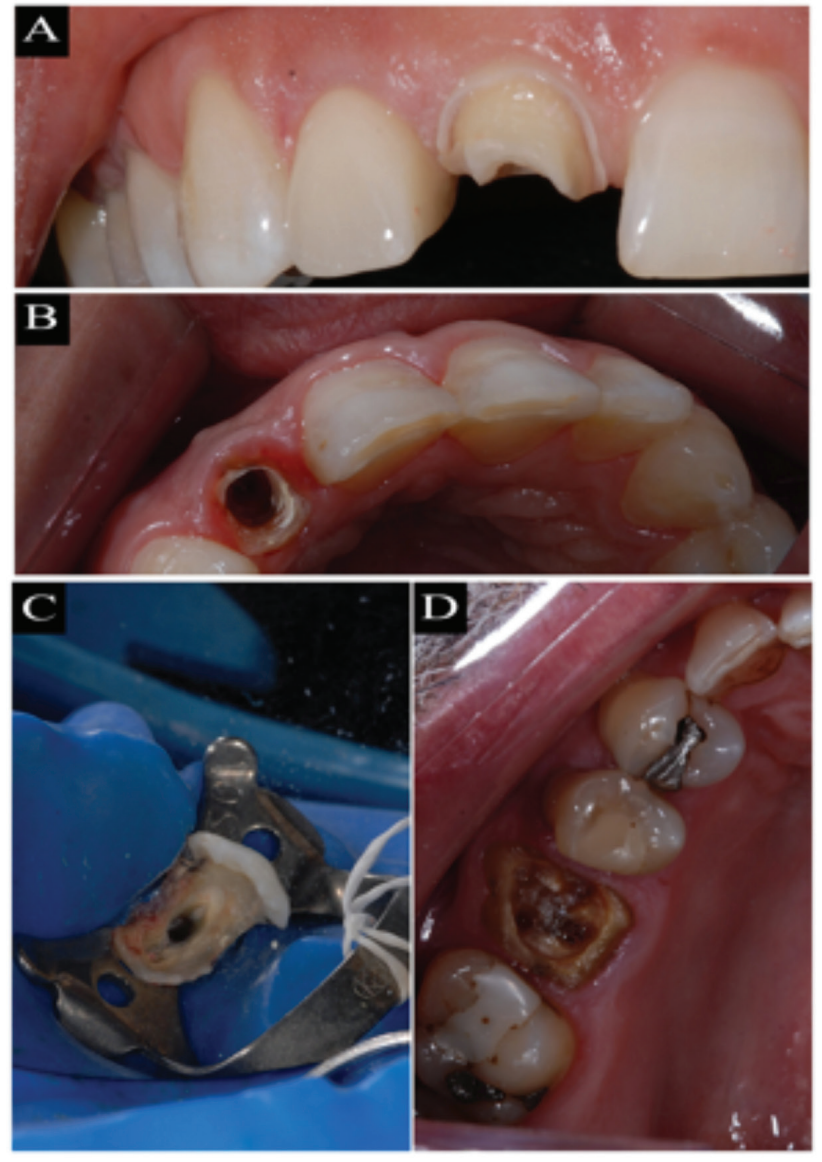

Figure 1- Pictures shown in the questionnaire.

selected with use of Excel program (Microsoft Co., Redmond, WA, EUA) based on the list of dentists registered on the Regional Dentistry Council section of Pelotas $(n=676)$. All dentists registered in the local council were considered eligible to participate of study but if the dentists selected were living in another city, had retired, could not be found, declined to participate or he/she was not located after three attempts or refused to participate, a new selection was carried out with use of previous list. The selected dentists were contacted by phone or personally aiming to schedule to respond the questionnaire. For the students the questionnaire was printed and for the dentists it was applied using a tablet (iPad mini Apple ${ }^{\circledR}$, Cupertino, CA, United
States). All students and dentists that answered the questionnaire signed informed consent.

Data was submitted to descriptive analysis and the association between educational level of the respondent (dentist or student) and interest variables was assessed by Logistic Regression Models, obtaining Odds Ratios (OR) and their respective 95\% confidence intervals. Level of confidence on the use of glass fiber-posts and resin cement in anterior and posterior ETT with large coronal destruction between groups was tested using t-test with considering $\alpha=5 \%$. Statistical analyses were performed using Stata 12.0 (StataCorp, College Station, TX, USA).

\section{RESULTS}

All students invited accepted to answer the questionnaire. To reach the desired sample of dentists, 207 dentists were contacted as 57 were unable to answer the questionnaire (17 were living in another city, 20 could not be found, 8 had retired, and 12 declined to participate).

Table I presents the characteristics of the participants. The mean ( \pm SD) age of dentists and students was $42.9( \pm 13.7)$ and $25.6( \pm 2.1)$ years old, respectively. Women were predominant in both groups. For dentists, the mean $( \pm S D)$ time since graduation was 18 ( \pm 13.4$)$ years, and most of the interviewed were specialists (80\%) and working in private practice $(60 \%)$.

Table II shows the comparison between the responses of students and dentists related to specific questions. Regarding the use of posts and cement in anterior teeth with large destruction of coronal portion the analysis showed that students presented an odd to choose pre-fabricated posts $127 \%$ greater, an odds $105 \%$ greater to choose self-adhesive resin cement and $46 \%$ greater to choose conventional resin cement, compared with dentists. Considering posterior teeth, students presented an odd $40 \%$ smaller to choose 
pre-fabricated posts and an odds 51\% greater to choose conventional resin cement than dentists.

Regarding to the function of intra-radicular posts (Table II), students had more than four times (CI: 1.62; 10.49) higher chances than dentists to believe that the posts help in the retention of the coronal restorative material. When asked about the reinforcement of the tooth structure using intra-radicular posts, students have $70 \%$ less chance to believe that posts are used to reinforce tooth structure, while students presented $60 \%$ less chance to choose composite resin than dentists to restore teeth with large coronal destruction.

Finally, the results for the level of confidence (Table III) on the use of glass fiberposts and resin cement in anterior and posterior ETT with large coronal destruction showed that dentists have a significantly higher degree of confidence than students $(\mathrm{P}<0.001)$.

Table I - General characteristics of the sample

\begin{tabular}{|c|c|c|}
\hline General Data & Dentists & Students \\
\hline Age (mean, SD) & $42.9(13.7)$ & $25.6(2.1)$ \\
\hline Gender (n, \%) - Female & $76(51 \%)$ & $96(64 \%)$ \\
\hline Male & $74(49 \%)$ & $54(36 \%)$ \\
\hline $\begin{array}{l}\text { Years since graduation* } \\
\text { (mean, SD) }\end{array}$ & $18(13.4)$ & NA \\
\hline Post-graduated dentists (n, \%) & $120(80 \%)$ & NA \\
\hline Workplace (n,\%) Public & $33(22 \%)$ & NA \\
\hline Private & $90(60 \%)$ & NA \\
\hline Both & $27(18 \%)$ & NA \\
\hline
\end{tabular}

${ }^{*}$ for dentists; NA: not applicable.
Table II - Comparison of students vs. dentists on interest variables considering all questions

\begin{tabular}{|c|c|c|}
\hline Question & $\begin{array}{l}\text { Odds Ratio } \\
(95 \%, \mathrm{Cl})\end{array}$ & P value \\
\hline $\begin{array}{l}\text { Considering picture } 1 \text { (anterior } \\
\text { tooth), which post would be } \\
\text { your first option? }\end{array}$ & & 0.002 \\
\hline - Cast metal & Reference & \\
\hline -Pre-fabricated & $2.27(1.36-3.78)$ & \\
\hline $\begin{array}{l}\text { Considering the previous } \\
\text { answer, which cement would } \\
\text { you use in this case? }\end{array}$ & & 0.05 \\
\hline -Zinc phosphate & Reference & \\
\hline -Glass ionomer & $1.09(0.42-2.85)$ & \\
\hline -Self-adhesive resin cement & $2.15(1.16-3.98)$ & \\
\hline - Conventional resin cement & $1.46(0.69-3.11)$ & \\
\hline $\begin{array}{l}\text { Considering picture } 1 \text { (poste- } \\
\text { rior tooth), which post would } \\
\text { be your first option? }\end{array}$ & & 0.090 \\
\hline - Cast metal & Reference & \\
\hline - Pre-fabricated & $0.60(0.33-1.08)$ & \\
\hline $\begin{array}{l}\text { Considering the previous } \\
\text { answer, which cement would } \\
\text { you use in this case? }\end{array}$ & & 0.296 \\
\hline -Zinc phosphate & Reference & \\
\hline - Glass ionomer & $0.82(0.36-1.90)$ & \\
\hline - Self-adhesive resin cement & $0.72(0.42-1.23)$ & \\
\hline - Conventional resin cement & $1.51(0.72-3.17)$ & \\
\hline $\begin{array}{l}\text { Do you believe in retention } \\
\text { of restorative material as a } \\
\text { function of intra-canal posts? }\end{array}$ & & 0.001 \\
\hline - No & Reference & \\
\hline - Yes & $4.13(1.62-10.49)$ & \\
\hline $\begin{array}{l}\text { Do you believe in reinforce- } \\
\text { ment of dental structure as a } \\
\text { function of intra-canal posts? }\end{array}$ & & $<0.001$ \\
\hline - No & Reference & \\
\hline - Yes & $0.29(0.18-0.47)$ & \\
\hline $\begin{array}{l}\text { Which type of restoration do } \\
\text { you use in teeth with large } \\
\text { coronal destruction? }\end{array}$ & & 0.090 \\
\hline -Crown & Reference & \\
\hline - Composite resin & $0.40(0.14-1.15)$ & \\
\hline
\end{tabular}


Table III - Confidence of dentists and students to use GFPs and resin cement in ETT

\begin{tabular}{|c|c|c|}
\hline Question & $\begin{array}{l}\text { Mean } \\
( \pm S D)\end{array}$ & Pvalue \\
\hline \multicolumn{3}{|c|}{$\begin{array}{l}\text { What is your confidence } \\
\text { level to use glass fiber posts } \\
\text { and resin cement in ETT with } \\
\text { a large coronal destruction? } \\
\text { (0-no confidence and } \\
10 \text {-totally confident) }\end{array}$} \\
\hline - Dentists & $6.92( \pm 1.98)$ & $<0.001$ \\
\hline - Students & $6.03( \pm 1.86)$ & \\
\hline
\end{tabular}

\section{DISCUSSION}

This is the first study to evaluate the relationship between students and dentists' choices regarding the use of intra-radicular posts to restore teeth with large coronal destruction. This study is important since there are many factors that may be related to the choice of the restorative treatment, as tooth location (anterior or posterior), type of post (metallic or not), restorative material and luting material (selfadhesive/regular resin cement, glass ionomer cement or zinc phosphate) and remaining tooth structure (also considering ferrule height and width). Also, studies based on questionnaires are important since they provide data about attitudes, opinions and choices of treatment [12]. The results of this study showed a difference in the choices of materials/techniques to restore ETT between dentists and students. Literature has shown that some factors could influence the choices of materials and techniques as workplace, time since graduation, post graduate training and capability to keep updated [9-11,13].

Based on the questions considering anterior teeth, students presented a higher chance to choose pre-fabricated posts and self-adhesive cement than dentists. Pre-fabricated posts, especially glass fiber posts have been presenting high rates of success in longitudinal studies and when luted with self-adhesive resin cement presenting higher values of bond strength to dentin than conventional resin cement [14-16].
Also, glass fiber posts have mechanical properties similar to that of dentin and could be associated to the reduction of the risk of catastrophic failures [17].

The mean time since graduation of dentists was 18 years and this could be related to the answers retrieved, as may be associated with a more conservative approach of dentists influencing the introduction of new technologies in their clinical practice since glass fiber posts were introduced in market recently compared with other posts. Furthermore, students could have a better understating of new possibilities of dental materials and techniques since they are in contact with the academia. However, the literature shows that the level of training of dentists can influence the clinical choices and, consequently, their practices $[9,11,18]$.

Considering posterior teeth, both groups presented preferences for the use of cast metal posts. These findings corroborate previous findings showing that cast metal posts are still used for dentists [11]. It is obvious that cast metal posts are the gold standard in literature to restore ETT with large coronal destruction as they present high success rates in longitudinal studies $[16,19]$. Yet, their mechanical properties different to dentin favour catastrophic failures. Zinc phosphate was the cement of choice for both groups relate to posterior teeth. This cement is widely used because of long history of success, lower price and less sensitive technique compared with resin cement. Comparing the results of anterior and posterior teeth it is important to point out that the position of tooth (anterior or posterior) can influence the results, which has been widely discussed in the literature once there is difference on the survival of ETT restorations in anterior and posterior teeth $[16,20]$.

Students presented less chance to indicate composite resin than dentists to restore ETT with no coronal walls. Restorations of resin composite have high survival rates, with the literature showing that the preservation of coronal walls 
reduces the chance of failure and the cases included in this study could be considered the worst-case scenario [21]. Metal-ceramic and metal-free crowns also present good survival when chosen to restore ETT [22]. Even considering that resin composite is a conservative procedure with advantages as easier repair compared with metal-ceramic and metal-free crowns, the fact that the questionnaires were applied to the students during prosthodontic classes could have influenced this result.

Dentists presented a higher chance to believe in the reinforcement of dental structure with the use of posts $[18,23,24]$. In comparable studies among dentists in UK, USA and Sweden a high rate of professionals with the same opinion was found $[18,23,24]$. This is divergent of the best evidence that the current literature presents showing that intra-radicular posts are used to provide a better retention for the restorative material to radicular portion and does not result in a reinforcement of the dental structure. Considering the level of confidence to use glass fiber posts and resin cement, dentists presented significantly higher confidence than students, which can be explained by their greater clinical experience. However, this confidence is not translated to clinical practice, since students with less confidence indicated more pre-fabricated posts and resin cement. Dentists believe on its clinical capacity but they still choose traditional restorative methods to restore teeth with large coronal destruction.

A limitation of the present study is related to the use of questionnaires in a cross-sectional survey. Furthermore, another limitation is that only $22.2 \%$ of dentists registered on the Regional Dentistry Council section of Pelotas participated of study influencing the extrapolation of results but it was attenuated by random selection of dentists. Also, it is important to note the low refusal rate (only 12 dentists). Therefore, it is expected that not only the more motivated dentists participated, and this is one advantage of a face-to-face interview compared to self applied questionnaires. Further studies are needed focusing on the level of continued education of dentists and students, evaluating access to scientific information, information sources comparing what dentists/students consider the gold standard and what the literature shows as gold-standard for certain situations.

Through this cross-sectional study, it was evidenced that dental schools seem to be in line with literature with students presenting preference for the use of pre-fabricated posts. Furthermore, the importance attending continuing education courses should be highlighted since dentists still present preference for the use of cast metal posts.

\section{CONCLUSION}

Being a student or a dentist was directly related to the clinical choices of the respondents. The choices of posts and cements seem to be related to the location of the tooth (anterior or posterior). Dentists and students present different perceptions and attitudes concerning techniques and materials to restore endodontically treated teeth.

\section{ACKNOWLEDGEMENT}

We would like to thank all the dentists and students for their participation in this study. We also thank CAPES for the scholarship provided for the first author. 


\section{REFERENCES}

1. Manhart J, Chen H, Hamm G, Hickel R. Buonocore Memorial Lecture. Review of the clinical survival of direct and indirect restorations in posterior teeth of the permanent dentition. Oper Dent. 2004 Sep-0ct;29(5):481-508.

2. Fernandes AS, Shetty S, Coutinho I. Factors determining post selection: a literature review. J Prosthet Dent. 2003 Dec;90(6):55662.

3. Mannocci F, Bertelli E, Sherriff M, Watson TF, Ford TR. Three-year clinical comparison of survival of endodontically treated teeth restored with either full cast coverage or with direct composite restoration. J Prosthet Dent. 2002 Sep;88(3):297-301.

4. Giachetti L, Grandini S, Calamai P, Fantini G, Scaminaci Russo D. Translucent fiber post cementation using light- and dual-curing adhesive techniques and a self-adhesive material: push-out test. $J$ Dent. 2009 Aug;37(8):638-42.

5. Theodosopoulou JN, Chochlidakis KM. A systematic review of dowel (post) and core materials and systems. J Prosthodont. 2009 Aug;18(6):464-72.

6. Piovesan EM, Demarco FF, Cenci MS, Pereira-Cenci T. Survival rates of endodontically treated teeth restored with fiber-reinforced custom posts and cores: a 97-month study. Int J Prosthodont. 2007 Nov-Dec;20(6):633-9.

7. Pegoraro TA, da Silva NR, Carvalho RM. Cements for use in esthetic dentistry. Dent Clin North Am. 2007 Apr;51(2):453-71,x.

8. Ricketts DN, Tait CM, Higgins AJ. Post and core systems, refinements to tooth preparation and cementation. Br Dent J. 2005 May;198(9):533-41.

9. Nascimento GG, Correa MB, Opdam N, Demarco FF. Do clinical experience time and postgraduate training influence the choice of materials for posterior restorations? Results of a survey with Brazilian general dentists. Braz Dent J. 2013 Nov-Dec;24(6):642-6.

10. Demarco FF, Baldissera RA, Madruga FC, Simoes RC, Lund RG, Correa MB, et al. Anterior composite restorations in clinical practice: findings from a survey with general dental practitioners. J Appl Oral Sci. 2013 Nov-Dec;21(6):497-504.

11. Sarkis-Onofre R, Pereira-Cenci T, Opdam NJ, Demarco FF. Preference for using posts to restore endodontically treated teeth: findings from a survey with dentists. Braz Oral Res. 2015 Nov;29(1):1-6.

12. Tortopidis D, Papa P, Menexes G, Koidis P. Attitudes of dentists regarding the restoration of root canal treated teeth: A survey in Greece. Int Dent J. 2010 0ct;60(5):336-42.
13. Naumann M, Neuhaus KW, Kolpin M, Seemann R. Why, when, and how general practitioners restore endodontically treated teeth: a representative survey in Germany. Clin Oral Investig. 2016 Mar;20(2):253-9.

14. Sarkis-Onofre R, Skupien JA, Cenci MS, Moraes RR, Pereira-Cenci $T$. The role of resin cement on bond strength of glass-fiber posts luted into root canals: a systematic review and meta-analysis of in vitro studies. Oper Dent. 2014 Jan-Feb;39(1):E31-44.

15. Skupien JA, Sarkis-Onofre R, Cenci MS, Moraes RR, PereiraCenci T. A systematic review of factors associated with the retention of glass fiber posts. Braz Oral Res. 2015;29. pii: S180683242015000100401. doi: 10.1590/1807-3107BOR-2015.vol29.0074. Epub 2015 Jun 16.

16. Sarkis-Onofre R, Jacinto Rde C, Boscato N, Cenci MS, Pereira-Cenci T. Cast metal vs. glass fibre posts: a randomized controlled trial with up to 3 years of follow up. J Dent. 2014 May;42(5):582-7.

17. Figueiredo FE, Martins-Filho PR, Faria ESAL. Do metal postretained restorations result in more root fractures than fiber postretained restorations? A systematic review and meta-analysis. J Endod. 2015 Mar;41(3):309-16.

18. Morgano SM, Hashem AF, Fotoohi K, Rose L. A nationwide survey of contemporary philosophies and techniques of restoring endodontically treated teeth. J Prosthet Dent. 1994 Sep;72(3):25967.

19. Zicari F, Van Meerbeek B, Debels E, Lesaffre E, Naert I. An up to 3 -Year Controlled Clinical Trial Comparing the Outcome of Glass Fiber Posts and Composite Cores with Gold Alloy-Based Posts and Cores for the Restoration of Endodontically Treated Teeth. Int J Prosthodont. 2011 Jul-Aug;24(4):363-72.

20. Torbjorner A, Fransson B. Biomechanical aspects of prosthetic treatment of structurally compromised teeth. Int J Prosthodont. 2004 Mar-Apr;17(2):135-41.

21. Skupien JA, Luz MS, Pereira-Cenci T. Ferrule Effect: A Metaanalysis. JDR Clinical \& Transl Res. 2016 March 1. Epub ahead of print. doi: 10.1177/2380084416636606.

22. Sailer I, Makarov NA, Thoma DS, Zwahlen M, Pjetursson BE. Allceramic or metal-ceramic tooth-supported fixed dental prostheses (FDPs)? A systematic review of the survival and complication rates. Part I: Single crowns (SCs). Dent Mater. 2015 Jun;31(6):60323.

23. Hussey DL, Killough SA. A survey of general dental practitioners' approach to the restoration of root-filled teeth. Int Endod J. 1995 Mar;28(2):91-4

24. Eckerbom M, Magnusson T. Restoring endodontically treated teeth: a survey of current opinions among board-certified prosthodontists and general dental practitioners in Sweden. Int $\mathrm{J}$ Prosthodont. 2001 May-Jun;14(3):245-9.

Tatiana Pereira-Cenci (Corresponding address) Rua Gonçalves Chaves, 457 Pelotas, RS, 96015-560, Brazil Phone/Fax: + 5553 3225-6741 E-mail: tatiana.dds@gmail.com

Date submitted: 2017 Sep 26 Accept submission: 2017 Dec 04 